\title{
PENGARUH KUALITAS PELAYANAN (SERVICE QUALITY) TERHADAP KEPUASAN PELANGGAN PT. SUCOFINDO BATAM
}

\author{
Alfi Syahri Lubis ${ }^{1}$ ), Nur Rahmah Andayani' ${ }^{2)}$ \\ 1) Prodi Administrasi Bisnis Terapan Politeknik Negeri Batam, email : afisyahri852@gmail.com \\ 2) Prodi Administrasi Bisnis Terapan Politeknik Negeri Batam, email : nunun@ polibatam.ac.id
}

\begin{abstract}
This study aims to determine and analyze the influence of service quality consisting of variable reliablility, responsiveness, assurance, empathy, and tangible to customer satisfaction PT. Sucofindo Batam simultaneously or partially. Population in this research is consumer of PT. Sucofindo Batam or consumers who have ever used the services of PT. Sucofindo Batam. The number of samples obtained using Slovin calculations A total of 80 respondents using Non Probability Sampling method. The method of analysis used in this study is descriptive analysis and multiple regression analysis using SPSS 20 program. From the results of the study showed that the persial and simultaneous positive and significant impact on customer satisfaction PT. Sucofindo Batam.
\end{abstract}

Keywords: Service quality, tangible, reliability, responsiveness, assurance, empathy, customer satisfaction

\begin{abstract}
Abstrak
Penelitian ini bertujuan untuk mengetahui dan menganalisis pengaruh kualitas pelayanan yang terdiri dari variabel reliablility, responsiveness, assurance, empathy, dan tangible terhadap kepuasan pelanggan PT. Sucofindo Batam secara simultan maupun parsial. Populasi dalam penelitian ini adalah konsumen PT. Sucofindo Batam atau konsumen yang penah menggunakan jasa PT. Sucofindo Batam. Jumlah sampel yang didapatkan menggunakan perhitungan Slovin Sebanyak 80 Responden dengan menggunakan metode Non Probability Sampling. Metode analisis yang digunakan dalam penelitian ini adalah analisis deskriptif dan analisis regresi berganda menggunakan program SPSS 20. Dari hasil penelitian menunjukkan bahwa kualitas pelayanan secara persial dan simultan berpengaruh positif dan signifikan terhadap kepuasan pelanggan PT. Sucofindo Batam.
\end{abstract}

Kata kunci : Kualitas layanan, tangible, reliability, responsiveness, assurance, empathy, Kepuasan pelanggan 


\section{PENDAHULUAN}

Perkembangan dunia bisnis saat ini mengalami pertumbuhan yang sangat pesat, baik bisnis yang bergerak di bidang jasa atau bidang non jasa. Perkembangan perekonomian secara menyeluruh yang diiringi dengan perkembangan teknologi dan ilmu pengetahuan menciptakan sebuah persaingan yang semakin ketat, baik di pasar domestik maupun pasar internasional. Oleh karena itu dalam persaingan yang demikian, perusahaan dituntut untuk dapat memuaskan pelanggannya dengan menciptakan produk atau jasa yang berkualitas sesuai dengan keinginan konsumen. Kualitas jasa merupakan tingkat keunggulan yang diharapkan dan pengendalian atas tingkat keunggulan tersebut bertujuan memenuhi keinginan pelanggan agar merasa puas.

Kualitas dapat diartikan sebagai derajat yang dicapai oleh karakteristik yang berkaitan dalam memenuhi persyaratan. Ada lima dimensi kualitas pelayanan jasa menurut (Tjiptono \& Chandra, 2011). Kualitas pelayanan yaitu Tangibles, Reliability, Responsiveness, Assurance dan Empathy, dimensi tersebut sangat berpengaruh terhadap kepuasan pelanggan. Kelima dimensi ini yang akan digunakan untuk mengukur tingkat kualitas layanan di suatu perusahaan.

Perkembangan bisnis dalam bidang jasa khususnya inspeksi, pengujian, serta sertifikasi, saat ini terlihat semakin ketat, yang membuat para pebisnis tidak hanya memberikan pelayanan terbaik melainkan juga bersaing dari segi harga, pelayanan, lokasi, suasana, hingga kemudahan transaksi. Hal ini menunjukkan bahwa bisnis dalam bidang jasa menjadi salah satu penunjang meningkatnya perekonomian di Batam. Sebagai salah satu wilayah yang berpotensi terhadap perkembangan bisnis, di Batam terdapat banyak perusahaan dan instansi yang menyediakan jasa berupa inspeksi, pengujian, serta sertifikasi.

Sucofindo adalah perusahaan inspeksi pertama di Indonesia yang 95\% sahamnya dikuasai oleh Negara Republik Indonesia dan 5\% dikuasai oleh Societe Generaled Surveillance (SGS) Holding, SA (Rayhan, 2010). Sucofindo berdiri pada 22 Oktober 1956 berawal dari perkembangan kegiatan perdagangan terutama terhadap komoditi pertanian, kelancaran arus barang dan pengamanan devisa negara dalam perdagangan ekspor impor. Melalui kreativitas,
Sucofindo melakukan inovasi jasa-jasa baru pada basis kompetensinya, seiring dengan perkembangan kebutuhan dunia usaha.

Kepuasaan pelanggan adalah tingkat perasaan seseorang setelah membandingkan kinerja atau hasil yang dirasakan dibandingkan dengan harapannya (Kotler \& Keller, 2007). Dari definisi di atas dapat ditarik kesimpulan bahwa kepuasan pelanggan yang ditinjau dari sisi pelanggan yaitu mengenai apa yang telah dirasakan pelanggan atas pelayanan yang telah diberikan dibandingkan dengan apa yang mereka inginkan. Sedangkan ketidakpuasan timbul apabila hasil yang diinginkan tidak memenuhi harapan. Kepuasan pelanggan terhadap suatu produk ataupun jasa, sebenarnya sesuatu yang sulit untuk didapat jika perusahaan jasa atau industri tersebut tidak benar-benar mengerti apa yang diharapkan oleh konsumennya.

Menurut (Lovelock \& Wirtz, 2011) Kepuasan adalah suatu sikap yang diputuskan berdasarkan pengalaman yang didapatkan. Kepuasan merupakan penilaian mengenai ciri atau keistimewaan produk, jasa, atau produk itu sendiri, yang menyediakan tingkat kesenangan konsumen berkaitan dengan pemenuhan kebutuhan konsumsi. Kepuasan konsumen dapat diciptakan melalui kualitas, pelayanan dan nilai. Kunci untuk menghasikan kesetiaan pelanggan adalah memberikan nilai pelanggan yang tinggi. Penelitian ini penting dilakukan agar dapat mengukur seberapa baik pelayanan yang telah diberikan, serta mengetahui sejauh mana pelayanan yang diberikan perusahaan Sucofindo selama ini, yang akan berpengaruh terhadap kepuasan pelanggannya. Dengan demikian diharapkan perusahaan dapat mengetahui serta mengantisipasi secara jelas tentang apa yang dibutuhkan dan diinginkan konsumen, sehingga perusahaan dapat menerapkan strategi yang tepat untuk menangani keluhan pelanggan, meningkatkan layanannya secara lebih baik, serta dapat bersaing dalam segmentasi pasar yang ada, agar tujuan perusahaan tercapai dan dapat berkembang di masa mendatang.

\section{Rumusan Masalah}

Berdasarkan latar belakang di atas, maka dirumuskan masalah sebagai berikut :

1. Sejauh mana pengaruh tangible $\left(\mathrm{X}_{1}\right)$ terhadap kepuasan pelanggan PT. Sucofindo Batam 
Alfi Syahri \& Nur Rahmah, Pengaruh Kualitas Pelayanan (Service Quality) terhadap...

2. Sejauh mana pengaruh reliability $\left(\mathrm{X}_{2}\right)$ terhadap kepuasan pelanggan PT. Sucofindo Batam

3. Sejauh mana pengaruh responsiveness $\left(\mathrm{X}_{3}\right)$ terhadap kepuasan pelanggan PT. Sucofindo Batam

4. Sejauh mana pengaruh assurance $\left(\mathrm{X}_{4}\right)$ terhadap kepuasan pelanggan PT. Sucofindo Batam

5. Sejauh mana pengaruh empathy $\left(\mathrm{X}_{5}\right)$ terhadap kepuasan pelanggan PT. Sucofindo Batam

6. Sejauh mana pengaruh tangible, reliability, responsiveness, assurance, empathy secara simultan terhadap kepuasan pelanggan PT. Sucofindo Batam.

\section{Tujuan Penelitian}

Berdasarkan perumusan masalah diatas, maka penulis merumuskan tujuan sebagai berikut :

1. Mengetahui sejauh mana pengaruh tangible $\left(\mathrm{X}_{1}\right)$ terhadap kepuasan pelanggan PT. Sucofindo Batam

2. Mengetahui sejauh mana pengaruh reliability $\left(\mathrm{X}_{2}\right)$ terhadap kepuasan pelanggan PT. Sucofindo Batam

3. Mengetahui sejauh mana pengaruh responsiveness terhadap $\left(\mathrm{X}_{3}\right)$ terhadap kepuasan pelanggan PT. Sucofindo Batam

4. Mengetahui sejauh mana pengaruh assurance terhadap $\left(\mathrm{X}_{4}\right)$ terhadap kepuasan pelanggan PT. Sucofindo Batam

5. Mengetahui sejauh mana pengaruh empathy $\left(\mathrm{X}_{5}\right)$ terhadap kepuasan pelanggan PT. Sucofindo Batam

6. Mengetahui sejauh mana pengaruh tangible, reliability, responsiveness, assurance, empathy secara simultan terhadap kepuasan pelanggan PT. Sucofindo Batam

\section{KAJIAN TEORI \\ Kualitas Pelayanan}

Kualitas pelayanan menurut (Kotler, 2008) adalah sebuah kinerja yang dapat ditawarkan oleh seseorang kepada orang lain. Kinerja ini dapat berupa tindakan yang tidak berwujud serta tidak berakibat pada kepemilikan barang apapun dan terhadap siapapun. Poin utamanya adalah pelayanan merupakan suatu tindakan yang dilakukan oleh seorang penjual kepada pembeli / konsumennya demi memenuhi kebutuhan dan keinginan konsumen. Perilaku tersebut bertujuan pada tercapainya kepuasan pelanggan itu sendiri. Sebuah pelayanan dapat dilakukan pada saat konsumen memilih produk maupun setelah selesai melakukan transaksi pembelian produk. Kualitas pelayanan yang baik akan memberikan dampak yang baik pula bagi perusahaan karena akan menjadi pelanggan yang loyal dan memberikan keuntungan bagi perusahaan

\section{Dimensi - dimensi Kualitas Pelayanan}

\section{a. Bukti fisik (Tangible)}

Bukti fisik merupakan suatu service yang bisa dilihat, bisa dicium dan bisa diraba, maka aspek tangible menjadi penting sebagai ukuran terhadap pelayanan. Bukti fisik suatu perusahaan dalam menunjukkan esksitensinya kepada pihak eksternal. Penampilan dan kemampuan sarana dan prasarana fisik perusahaan dan keadaan lingkungan sekitarnya adalah bukti nyata dari pelayanan yang diberikan oleh pemberi jasa yang meliputi fasilitas fisik perlengkapan, pegawai, dan sarana komunikasi. Tangible yang baik akan mempengaruhi persepsi pelanggan.

\section{b. Kehandalan (Reliability)}

Reliability merupakan kemampuan perusahaan untuk melaksanakan jasa sesuai dengan apa yang telah dijanjikan secara tepat waktu. Pentingnya dimensi ini adalah kepuasan konsumen akan menurun bila jasa yang diberikan tidak sesuai dengan yang dijanjikan. Jadi komponen atau unsur dimensi reliability ini merupakan kemampuan perusahaan dalam menyampaikan jasa secara tepat dan pembebanan biaya secara tepat.

\section{c. Ketanggapan (Responsiveness)}

Merupakan kemampuan perusahaan yang dilakukan langsung oleh karyawan untuk memberikan pelayanan dengan cepat dan tanggap. Daya tanggap dapat menumbuhkan persepsi yang positif terhadap kualitas jasa yang diberikan. Termasuk didalamnya jika terjadi kegagalan atau keterlambatan dalam penyampaian jasa, pihak penyedia jasa 
berusaha memperbaiki atau meminimalkan kerugian konsumen dengan segera. Dimensi ini menekankan pada perhatian dan kecepatan karyawan yang terlibat untuk menanggapi permintaan, pertanyaan, dan keluhan konsumen. Jadi komponen atau unsur dari dimensi ini terdiri dari kesigapan karyawan dalam melayani pelanggan, kecepatan karyawan dalam melayani pelanggan dan penanganan keluhan pelanggan.

\section{d. Jaminan (Assurance)}

Merupakan pengetahuan dan perilaku employee untuk membangun kepercayaan dan keyakinan pada diri konsumen dalam mengkonsumsi jasa yang ditawarkan. Dimensi ini sangat penting karena melibatkan persepsi konsumen terhadap resiko ketidakpastian yang tinggi terhadap kemampuan penyedia jasa. Perusahaan membangun kepercayaan dan kesetiaan konsumen melalui karyawan yang terlibat langsung menangani konsumen. Jadi komponen dari dimensi ini terdiri dari kompotensi karyawan yang meliputi ketrampilan, pengetahuan yang dimiliki karyawan untuk melakukan pelayanan dan kredibilitas perusahaan yang meliputi hal-hal yang berhubungan dengan kepercayaan konsumen kepada perusahaan seperti, reputasi perusahaan, prestasi dan lain-lain.

\section{e. Empati (Empathy)}

Merupakan kemampuan perusahaan yang dilakukan langsung oleh karyawan untuk memberikan perhatian kepada konsumen secara individu, termasuk juga kepekaan atau kebutuhan konsumen. Jadi komponen dari dimensi ini merupakan gabungan dari akses (access) yaitu kemudahan untuk memanfaatkan jasa yang ditawarkan oleh perusahaan.

\section{Kepuasan Pelanggan}

Kepuasaan pelanggan adalah tingkat perasaan seseorang setelah membandingkan kinerja atau hasil yang dirasakan dibandingkan dengan harapannya (Kotler \& Keller, 2007). Dari definisi di atas dapat ditarik kesimpulan bahwa kepuasan pelanggan yang ditinjau dari sisi pelanggan yaitu mengenai apa yang telah dirasakan pelanggan atas pelayanan yang telah diberikan dibandingkan dengan apa yang mereka inginkan. Kepuasan adalah tingkat perasaan seseorang setelah membandingkan kinerja atau hasil yang dia rasakan dibandingkan dengan harapannya. Sedangkan ketidakpuasan timbul apabila hasil tidak memenuhi harapan. Kepuasan pelanggan terhadap suatu produk ataupun jasa, sebenarnya sesuatu yang sulit untuk didapat jika perusahaan jasa atau industri tersebut tidak benar-benar mengerti apa yang diharapkan oleh konsumennya.

\section{METODE}

Penelitian yang akan dilakukan adalah menggunakan pendekatan penelitian eksplanatori (Explanatory Research), yaitu penelitian yang menjelaskan hubungan kausal antara variabel penelitian dengan pengujian hipotesa. Di dalam penelitian eksplanatori, pendekatan yang dipakai dalam penelitian ini adalah metode survei atau penelitian yang dilakukan untuk memperoleh fakta-fakta mengenai fenomena-fenomena yang ada di dalam obyek penelitian dan mencari keterangan secara aktual dan sistematis. Lokasi penelitian ini dilaksanakan di PT. Sucofindo Batam pada bulan Mei - Juni tahun 2017.

Variabel yang diteliti adalah variabel Tangible (X1), Realibility (X2), Responsiveness (X3), Assurance (X4), Emphaty (X5) dan Kepuasan Pelanggan di PT. Sucofindo Batam. Dalam penelitian ini, populasi yang dipilih adalah konsumen PT. Sucofindo Batam.

Sampel dalam penelitian ini sebanyak 80 orang responden, dengan rumus Slovin. Data yang diambil dalam penelitian berasal dari data primer, yaitu data yang diperoleh langsung dari responden melalui kuesioner dan dokumentasi yaitu data-data yang diperoleh dari setiap bagian yang berkaitan dengan penelitian, seperti profil perusahaan, struktur organisasi, dan lain-lain yang mendukung penelitian ini.

\section{Analisis Data}

Data yang diperoleh dianalisis dengan menggunakan analisis deskriptif dan analisis inferensial. Analisis deskriptif digunakan untuk mengetahui gambaran responden yang menjadi subjek penelitian. Langkah pertama dalam analisis inferensial yaitu Uji Asumsi Klasik yang terdiri dari uji normalitas, uji multikolinieritas, dan uji heteroskedastisitas. Selanjutnya digunakan analisis regresi linier 
Alfi Syahri \& Nur Rahmah, Pengaruh Kualitas Pelayanan (Service Quality) terhadap...

berganda digunakan untuk mengetahui besarnya pengaruh langsung dan tidak langsung antar variabel yang digunakan dalam penelitian ini. Serta melakukan pengujian hipotesis dengan Uji $\mathrm{t}$ (Parsial) digunakan untuk mengetahui pengaruh dari masing-masing variabel, baik variabel bebas terhadap variabel terikat tersebut yang signifikan secara statistik. Menggunakan uji masing-masing koefisien regresi variabel bebas apakah mempunyai pengaruh yang bermakna atau tidak terhadap variabel terikat dan Uji F (simultan) untuk mengetahui secara keseluruhan variabel bebas terhadap variabel terikat apakah mmpunyai pengaruh secara keseluruhan variabel bebas terhadap variabel terikat yang signifikan secara statistik.

\section{HASIL DAN PEMBAHASAN}

Metode pengujian dengan menggunakan statistik deskriptif dan statistik inferensial, penulis ingin menguji pengaruh antara variabel bebas terhadap variabel terikat.

Dimana Hasil analisis deskriptif menunjukkan bahwa responden yang menjadi objek dalam penelitian ini terdiri dari 55\% orang laki-laki dan $45 \%$ orang perempuan. Sebagian besar responden dalam penelitian ini dengan karakteristik berdasarkan lama menjadi pelanggan <3 Bulan sebanyak 15\% responden, 3-6 Bulan sebanyak 7,5\% responden, 6-12 Bulan sebanyak $15 \%$ responden, $>12$ Bulan sebanyak $62,5 \%$ responden.

\section{Uji Asumsi Klasik}

\section{Uji Normalitas}

Uji statistik sederhana yang sering digunakan untuk menguji asumsi normalitas adalah dengan menggunakan uji normalitas dari Kolmogorov Smirnov. Metode pengujian normal tidaknya distribusi data dilakukan dengan melihat nilai signifikansi variabel, jika signifikan lebih besar dari alpha $10 \% \quad(0.1)$, maka menunjukkan distribusi data normal.

\section{Tabel 1. Uji Normalitas}

\begin{tabular}{ll}
\hline & $\begin{array}{l}\text { Unstandardized } \\
\text { Residual }\end{array}$ \\
\hline Kolmogorov-Smirnov & 0.738 \\
$\mathbf{Z}$ & \\
\hline
\end{tabular}

Asymp. Sig. (2-tailed) 0.648

Sumber: Data diolah, 2017

Tabel diatas menunjukkan bahwa nilai signifikansi variabel yaitu sebesar 0.738 lebih besar dari alpha 0.1, ini menunjukkan bahwa distribusi data dinyatakan normal.

\section{Uji Multikolinieritas}

Pengujian ada tidaknya gejala multikolinieritas dilakukan dengan memperhatikan nilai matriks kolerasi yang dihasilkan pada saat pengolahan data serta nilai VIF (Variance Inflation Factor) dan tolerancenya.

Tabel 2. Uji Multikolinieritas

\begin{tabular}{llll}
\hline Model & $\begin{array}{l}\text { Colinearity } \\
\text { Statistics }\end{array}$ & Keterangan \\
\cline { 2 - 3 } & Tolerance & VIF & \\
\hline Tangible $\left(\mathbf{X}_{\mathbf{1}}\right)$ & 0.595 & 1.682 & $\begin{array}{l}\text { Bebas } \\
\text { Multikolinieritas }\end{array}$ \\
\hline Reliability $\left(\mathbf{X}_{\mathbf{2}}\right)$ & 0.607 & 1.646 & $\begin{array}{l}\text { Bebas } \\
\text { Multikolinieritas }\end{array}$ \\
\hline $\begin{array}{l}\text { Responsiveness } \\
\left(\mathbf{X}_{\mathbf{3}}\right)\end{array}$ & 0.555 & 1.802 & $\begin{array}{l}\text { Bebas } \\
\text { Multikolinieritas }\end{array}$ \\
\hline Assurance $\left(\mathbf{X}_{\mathbf{4}}\right)$ & 0.434 & 2.305 & $\begin{array}{l}\text { Bebas } \\
\text { Multikolinieritas }\end{array}$ \\
\hline Emphaty $\left(\mathbf{X}_{\mathbf{5}}\right)$ & 0.456 & 2.194 & $\begin{array}{l}\text { Bebas } \\
\text { Multikolinieritas }\end{array}$ \\
\hline
\end{tabular}

Sumber: Data diolah, 2017

Berdasarkan tabel di atas dapat dilihat bahwa setiap variabel mempunyai nilai tolerance $>0.1$ dan nilai $\mathrm{VIF}<10$, sehingga dapat disimpulkan bahwa tidak terjadi multikolinieritas antara variabel bebas dalam model regresi ini.

\section{Uji Heteroskedastisitas}

Salah satu cara untuk melihat ada tidaknya heteroskedastisitas adalah menggunakan uji Glejser. Uji ini dilakukan dengan cara melakukan regersi variabel bebas dengan nilai absolut dari residualnya.

\section{Tabel 3. Uji \\ Heteroskedastisita}

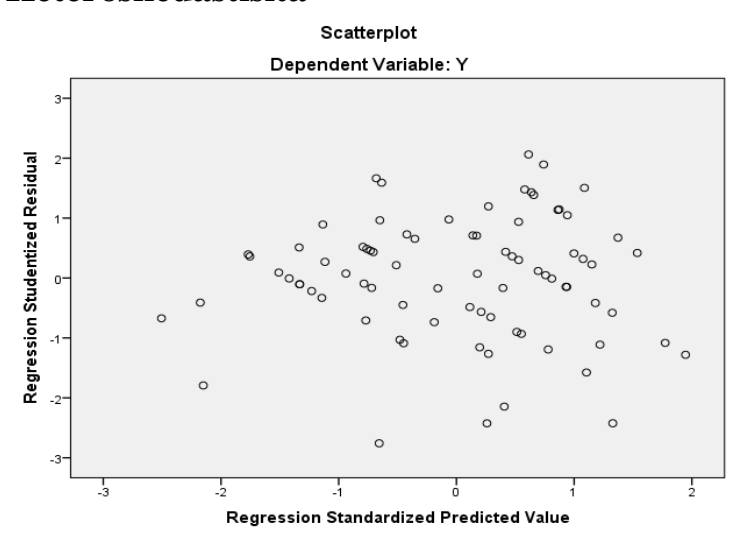

Sumber: Data diolah, 2017

Berdasarkan tabel di atas dapat dilihat bahwa hasil uji heteroskedastisitas dapat di deteksi dengan melihat ada tidaknya pola tertentu pada grafik scatterplot, hal tersebut menunjukkan bahwa tidak terdapat pola tertentu, serta titik- 
titik menyebar di atas dan di bawah angka 0 pada sumbu $Y$ sehingga dapat diartikan bahwa model regresi tidak memiliki gejala adanya heteroskedastisitas, atau terdapat kesamaan varian dari residual satu pengamatan ke pengamatan lain. Pada Grafik Scatterplot yang disajikan, terlihat titik-titik menyebar secara acak tidak membentuk sebuah pola tertentu yang jelas serta tersebar baik di atas maupun di bawah angka nol pada sumbu Y. Hal ini berarti tidak terjadi Heteroskedastisitas, yang terjadi adalah Homokedastisitas pada model regresi, sehingga model regresi layak digunakan untuk memprediksi kepuasan pelanggan berdasarkan masukan dari variabel independennya yaitu Tangible (X1), Reliability (X2), Responsiveness (X3), Assurance (X4) dan Empathy (X5) (tangible).

\section{Analisis Regresi Linier Berganda}

Analisis regresi linier berganda digunakan untuk mengetahui kekuatan hubungan dari variabel independen terhadap variabel dependen yaitu pengaruh kualitas pelayanan berupa variabel Tangible, Realibility, Responsiveness, Assurance, Emphaty terhadap Kepuasan pelanggan di PT. Sucofindo Batam.

Hasil pengolahan data dengan menggunakan program SPSS selengkapnya akan dijelaskan pada Tabel berikut ini.

\begin{tabular}{lllll}
$\begin{array}{l}\text { Tabel 4. } \\
\text { Berganda }\end{array}$ & Hasil Analisis & Regresi & Linier \\
\hline $\begin{array}{l}\text { Variabel } \\
\text { Dependen }\end{array}$ & $\begin{array}{l}\text { Variabel } \\
\text { Indenpenden }\end{array}$ & B & T & Sig. \\
\hline
\end{tabular}

\begin{tabular}{|c|c|c|c|c|}
\hline \multirow{4}{*}{$\begin{array}{l}\text { Kepuasan } \\
\text { Pelanggan } \\
\text { (Y) }\end{array}$} & Tangible (X1) & 0.160 & 1.723 & 0.012 \\
\hline & $\begin{array}{l}\text { Reliability } \\
\text { (X2) }\end{array}$ & 0.058 & 1.691 & 0.050 \\
\hline & $\begin{array}{l}\text { Responsiveness } \\
\text { (X3) }\end{array}$ & 0.261 & 2.144 & 0.035 \\
\hline & $\begin{array}{l}\text { Assurance } \\
\text { (X4) }\end{array}$ & 0.046 & 2.371 & 0.072 \\
\hline
\end{tabular}

$$
\text { Emphaty (X5) } \quad 0.612 \quad 4.263 \quad 0.000
$$

\section{Sumber: Data diolah, 2017}

Koefisien regresi dari variabel Tangible, Realibility, Responsiveness, Assurance, Emphaty memiliki arah positif dan signifikan dalam pengaruhnya terhadap Kepuasan pelanggan di PT. Sucofindo Batam.

Adapun bentuk model persamaan regresi dapat dituliskan dalam model persamaan sebagai berikut:

$$
\begin{aligned}
& Y=0,075+0.160 X_{1}+0.058 X_{2}+0.261 X_{3}+ \\
& 0.046 X_{4}+0.612 X_{5}
\end{aligned}
$$

\section{Model Persamaan Regresi Linier Berganda}

a. Constanta memiliki nilai sebesar 0,075 yang berarti jika variabel Tangible (X1), Reliability (X2), Responsiveness (X3), Assurance (X4) dan Empathy (X5) bernilai 0 , maka variabel Kepuasan pelanggan memiliki nilai sebesar 0,075 .

b. Variabel Tangible (X1) memiliki koefisien sebesar 0,160 ini berarti jika variabel independen lain yang nilainya tetap atau tidak berubah, maka kenaikan satu poin variabel Tangible (X1) akan meningkatkan nilai Kepuasan Pelanggan (Y) 0,160 poin. Koefisien variabel Tangible (X1) bernilai positif artinya ada hubungan positif antara Tangible (X1) dengan Kepuasan Pelanggan (Y), yang mana untuk nilai Tangible (X1) semakin meningkat , maka akan meningkat pula Kepuasan Pelanggan PT. Sucofindo Batam (Y).

c. Variabel Reliabbility (X2) memiliki koefisien sebesar 0,058 ini berarti jika variabel independen lain yang nilainya tetap atau tidak berubah, maka kenaikan satu poin variabel Reliability (X2) akan meningkatkan nilai Kepuasan Pelanggan (Y) 0,058 poin. Koefisien variabel Reliability (X2) bernilai positif artinya ada hubungan positif antara Reliability (X2) dengan Kepuasan Pelanggan (Y), yang mana untuk nilai Reliability (X2) semakin meningkat, maka akan meningkat pula Kepuasan Pelanggan PT. Sucofindo Batam (Y).

d. Variabel Responsiveness (X3) memiliki koefisien sebesar 0,261 ini berarti jika variabel independen lain yang nilainya tetap atau tidak berubah, maka kenaikan satu poin variabel Responsiveness (X3) akan meningkatkan nilai Kepuasan Pelanggan (Y) 0,261 poin. Koefisien variabel Responsiveness (X3) bernilai 
Alfi Syahri \& Nur Rahmah, Pengaruh Kualitas Pelayanan (Service Quality) terhadap...

positif artinya ada hubungan positif antara Responsiveness (X3) dengan Kepuasan Pelanggan (Y), yang mana untuk nilai Responsiveness (X3) semakin meningkat, maka akan meningkat pula Kepuasan Pelanggan PT. Sucofindo Batam (Y).

e. Variabel Assurance (X4) memiliki koefisien sebesar 0,046 ini berarti jika variabel independen lain yang nilainya tetap atau tidak berubah, maka kenaikan satu poin variabel Assurance (X4) akan meningkatkan nilai Kepuasan Pelanggan (Y) 0,046 poin. Koefisien variabel Assurance (X4) bernilai positif artinya ada hubungan positif antara Assurance (X4)) dengan Kepuasan Pelanggan (Y), yang mana untuk nilai Assurance (X4) semakin meningkat, maka akan meningkat pula Kepuasan Pelanggan PT. Sucofindo Batam (Y).

f. Variabel Emphaty (X5) memiliki koefisien sebesar 0,612 ini berarti jika variabel independen lain yang nilainya tetap atau tidak berubah, maka kenaikan satu poin variabel Emphaty (X5) akan meningkatkan nilai Kepuasan Pelanggan (Y) 0,612 poin. Koefisien variabel Emphaty (X5) bernilai positif artinya ada hubungan positif antara Emphaty (X5) dengan Kepuasan Pelangggan (Y), yang mana untuk nilai Emphaty (X5) semakin meningkat, maka akan meningkat pula Kepuasan Pelanggan PT. Sucofindo Batam (Y).

\section{Pengujian Hipotesis \\ Uji t (Parsial)}

Uji statistik $t$ dilakukan untuk mengetahui pengaruh masing-masing variabel terhadap variabel dependen secara parsial. Pengujian $t$ yang dilakukan menggunakan nilai $\alpha$ (alpha) sebesar $10 \%$. Dengan demikian perhitungan uji t dapat dilihat melalui $t_{\text {tabel }}$ yang memiliki alpha $10 \%$ atau 0.1 dan nilai derajat kebebasan (df) yang akan digunakan. Pengujian $t$ ini memiliki ketentuan sebagai berikut:

a. Jika $t_{\text {hitung }}>\mathbf{t}_{\text {tabel }}$ dan nilai signifikansi $<$ 0.1 maka Ho ditolak dan Ha diterima, jadi variabel independen (X) berpengaruh signifikan terhadap variabel dependen $(\mathrm{Y})$

b. Jika $t_{\text {hitung }}<t_{\text {tabel }}$ dan nilai signifikansi $>$ 0.1 maka Ho diterima dan Ha ditolak, jadi veriabel indenpenden (X) tidak berpengaruh signifikan terhadap variabel dependen $(\mathrm{Y})$.

Penelitian ini menggunakan signifikansi 0.1 dengan derajat kebebasan $(\mathrm{df})=\mathrm{n}-2$ dengan perhitungan bahwa jumlah responden (n) sebesar 100 maka nilai df $=80-2$ yaitu 78 . Maka dapat dilihat pada tabel statistik pada nilai signifikansi 0.1 dengan nilai df sebesar 78 diperoleh tabel sebesar 1,66.

Tabel 5. Hasil uji t

\begin{tabular}{|l|l|l|l|l|}
\hline $\begin{array}{l}\text { Variabel } \\
\text { Depende } \\
\mathbf{n}\end{array}$ & $\begin{array}{l}\text { Variabel } \\
\text { Indenpen } \\
\text { den }\end{array}$ & $\mathbf{B}$ & $\mathbf{T}$ & Sig. \\
\hline \multirow{4}{*}{$\begin{array}{l}\text { Kepuasa } \\
\mathrm{n} \\
\begin{array}{l}\text { Pelangga } \\
\mathrm{n} \\
(\mathrm{Y})\end{array}\end{array}$} & $\begin{array}{l}\text { Tangible } \\
\left(\mathrm{X}_{1}\right)\end{array}$ & .075 & .045 & .064 \\
\cline { 2 - 5 } & $\begin{array}{l}\text { Reliability } \\
\left(\mathrm{X}_{2}\right)\end{array}$ & .058 & 1.691 & .050 \\
\cline { 2 - 5 } & $\begin{array}{l}\text { Responsiv } \\
\text { eness }\left(\mathrm{X}_{3}\right)\end{array}$ & .261 & 2.144 & .035 \\
\cline { 2 - 5 } & $\begin{array}{l}\text { Assurance } \\
\left(\mathrm{X}_{4}\right)\end{array}$ & .046 & 2.371 & .072 \\
\cline { 2 - 5 } & $\begin{array}{l}\text { Emphaty } \\
\left(\mathrm{X}_{5}\right)\end{array}$ & .612 & 4.263 & .000 \\
\hline
\end{tabular}

Sumber: Data diolah, 2017

\section{a. Hipotesis Variabel Tangible}

Berdasarkan Hipotesis 1 ada pengaruh positif dan signifikan antara variable $\mathrm{X}_{1}$ terhadap kepuasan pelanggan (Y). Hipotesis ini di dukung apabila nilai probabilitas signifikansi menunjukkan nilai $<0,1$. Berdasarkan table di atas dapat dilihat bahwa variabel Tangible $\left(X_{I}\right)$ di peroleh $t_{\text {hitung }}$ sebesar 1,723 dengan signifikansi sebesar 0,012 (sig. $<0,1$ ). Hasil penelitian tersebut menunjukkan angka signifikansi jauh lebih kecil dari 0,1 dan $t_{\text {hitung }}$ sebesar 1,723 $>\mathrm{t}_{\text {tabel }}$ sebesar 1,66, maka model 
regresi dapat digunakan untuk memprediksi variabel dependen, atau dengan kata lain variabel Tangible $\left(X_{1}\right)$ berpengaruh secara positif dan signifikan terhadap variabel kepuasan pelanggan $(\mathrm{Y})$. Berdasarkan analisis tersebut maka disimpulkan hipotesis 1 dalam penelitian ini diterima.

\section{b. Hipotesis Variabel Reliability}

Berdasarkan Hipotesis 2 ada pengaruh positif dan signifikan antara variable $\mathrm{X}_{2}$ terhadap kepuasan pelanggan (Y). Hipotesis ini di dukung apabila nilai probabilitas signifikansi menunjukkan nilai $<0,1$. Berdasarkan table di atas dapat dilihat bahwa variabel Realibility $\left(X_{2}\right)$ di peroleh thitung sebesar 1,691 dengan signifikansi sebesar 0,050 (sig. < 0,1). Hasil penelitian tersebut menunjukkan angka signifikansi jauh lebih kecil dari 0,1 dan thitung sebesar $1,641>t_{\text {tabel }}$ sebesar 1,66, maka model regresi dapat digunakan untuk memprediksi variabel dependen, atau dengan kata lain variabel Realibility $\left(X_{2}\right)$ berpengaruh secara positif dan signifikan terhadap variabel kepuasan pelanggan (Y). Berdasarkan analisis tersebut maka disimpulkan hipotesis 2 dalam penelitian ini diterima.

\section{c. Hipotesis Variabel Responsiveness}

Berdasarkan Hipotesis 3 ada pengaruh positif dan signifikan antara variable $\mathrm{X}_{3}$ terhadap kepuasan pelanggan (Y). Hipotesis ini di dukung apabila nilai probabilitas signifikansi menunjukkan nilai $<0,1$. Berdasarkan table di atas dapat dilihat bahwa variabel Responsiveness $\left(X_{3}\right)$ di peroleh $t_{h i t u n g}$ sebesar 2,144 dengan signifikansi sebesar 0,035 (sig. < 0,1 ). Hasil penelitian tersebut menunjukkan angka signifikansi jauh lebih kecil dari 0,1 dan $\mathrm{t}_{\text {hitung }}$ sebesar 2,144 $>\mathrm{t}_{\text {tabel }}$ sebesar 1,66, maka model regresi dapat digunakan untuk memprediksi variabel dependen, atau dengan kata lain variabel Responsiveness $\left(X_{3}\right)$ berpengaruh secara positif dan signifikan terhadap variabel kepuasan pelanggan (Y). Berdasarkan analisis tersebut maka disimpulkan hipotesis 3 dalam penelitian ini diterima.

\section{d. Hipotesis Variabel Assurance}

Berdasarkan Hipotesis 4 ada pengaruh positif dan signifikan antara variable $\mathrm{X}_{4}$ terhadap kepuasan pelanggan (Y). Hipotesis ini di dukung apabila nilai probabilitas signifikansi menunjukkan nilai $<0,1$. Berdasarkan table di atas dapat dilihat bahwa variabel Assurance $\left(X_{4}\right)$ di peroleh thitung sebesar 2,371 dengan signifikansi sebesar 0,072 (sig. $<0,1)$. Hasil penelitian tersebut menunjukkan angka signifikansi jauh lebih kecil dari 0,1 dan $t_{\text {hitung }}$ sebesar 2,371 > $\mathrm{t}_{\text {tabel }}$ sebesar 1,66, maka model regresi dapat digunakan untuk memprediksi variabel dependen, atau dengan kata lain variabel Assurance $\left(X_{4}\right)$ berpengaruh secara positif dan signifikan terhadap variabel kepuasan pelanggan $(\mathrm{Y})$. Berdasarkan analisis tersebut maka disimpulkan hipotesis 4 dalam penelitian ini diterima.

\section{e. Hipotesis Variabel Emphaty}

Berdasarkan Hipotesis 5 ada pengaruh positif dan signifikan antara variable $\mathrm{X}_{5}$ terhadap kepuasan pelanggan (Y). Hipotesis ini di dukung apabila nilai probabilitas signifikansi menunjukkan nilai $<0,1$. Berdasarkan table di atas dapat dilihat bahwa variabel Emphaty $\left(X_{5}\right)$ di peroleh $t_{\text {hitung }}$ sebesar 4,263 dengan signifikansi sebesar 0,000 (sig. < 0,1). Hasil penelitian tersebut menunjukkan angka signifikansi jauh lebih kecil dari 0,1 dan thitung sebesar 4,263 > $t_{\text {tabel }}$ sebesar 1,66, maka model regresi dapat digunakan untuk memprediksi variabel dependen, atau dengan kata lain variabel Emphaty $\left(X_{5}\right)$ berpengaruh secara positif dan signifikan terhadap variabel kepuasan pelanggan (Y). Berdasarkan analisis tersebut maka disimpulkan hipotesis 5 dalam penelitian ini diterima.

\section{f. Hipotesis Variabel Kepuasan Pelanggan PT Sucofindo}

Hipotesis ini menyatakan berdasarkan hasil Uji Anova atau Uji Statistik F dapat diketahui bahwa secara bersama-sama (simultan) variabel independen memeiliki pengaruh yang signifikan terhadap variabel dependen. Hal ini terbukti dengan $F_{\text {hitung }} 17.852>F_{\text {tabel }} 1,93$ dengan nilai signifikansi sebesar $0,000<0,1$ karena nilai signifikansi lebih kecil dari 0,1 maka model regresi dapat digunakan untuk memprediksi Kepuasan Pelanggan atau dapat dikatakan variabel Kualitas Layanan yaitu Tangible (X1), Reliability (X2), Responsiveness (X3), Assurance (X4) dan Emphaty (X5) secara bersama-sama berpengaruh terhadap Kepuasan Pelanggan (Y). Berdasarkan Hipotesis 6 maka 
Alfi Syahri \& Nur Rahmah, Pengaruh Kualitas Pelayanan (Service Quality) terhadap...

variabel Kualitas Layanan berpengaruh secara simultan terbukti dan dapat diterima.

\section{Kajian Empiris \\ Pembahasan Penelitian}

Penelitian ini bertujuan untuk menguji dan menganalisis bagaimana pengaruh antara variabel independen, yaitu Reliability (X1), Responsiveness (X2), Assurance (X3), Empathy (X4) dan Tangible (X5) terhadap variabel dependen yaitu kepuasan pelanggan pada PT. Sucofindo Batam. Populasi dalam penelitian ini adalah pelanggan atau Costumer PT. Sucofindo Batam.

\section{Pengaruh Tangible $\left(\mathrm{X}_{1}\right)$ Terhadap Kepuasan Pelanggan (Y)}

Faktor ini memiliki 4 item pertanyaan. Dilihat dari tabel hasil uji konstanta dan koefisien regresi diketahui bahwa setiap kenaikan 1 poin atau $1 \%$ dari faktor tangible $\left(\mathrm{X}_{1}\right)$ mengakibatkan kepuasan pelanggan (Y) mengalami peningkatan sebesar 0,160 atau $16,0 \%$. Dari hasil uji t untuk variabel yang sama adalah memiliki nilai signifikan 0,012 dimana nilai tersebut lebih kecil dari 0,1 sehingga mempunyai pengaruh positif dan signifikan terhadap kepuasan pelanggan PT. Sucofindo Batam.

Dalam penelitian ini tangible $\left(\mathrm{X}_{1}\right)$ sangat diperhatikan kerana pesaing PT. Sucofindo semakin bertambah banyak sehingga PT. Sucofindo Batam terus meningkatkan tangible $\left(\mathrm{X}_{1}\right)$ dalam pernyataan fasilitas fisik sesuai dengan jenis jasa yang ditawarkan di PT. Sucofindo Batam, karena sebagian pelanggan memberikan respon kurang baik sehingga harus lebih ditingkatkan agar lebih baik lagi. Hasil ini selaras dengan penelitian yang dilakukan oleh Aliftia Rizki Annisa (2014), dengan jurnal yang berjudul "Pengaruh Kualitas Pelayanan Jasa Verifikasi Impor Terhadap Kepuasan Dan Loyalitas Pelanggan PT Surveyor Indonesia (Persero)"

\section{Pengaruh Realibility $\left(\mathbf{X}_{2}\right) \quad$ Terhadap Kepuasan Pelanggan (Y)}

Faktor ini memiliki 4 item pertanyaan. Dilihat dari tabel hasil uji konstanta dan koefisien regresi diketahui bahwa setiap kenaikan 1 poin atau $1 \%$ dari faktor realibility $\left(\mathrm{X}_{2}\right)$ mengakibatkan kepuasan pelanggan $(\mathrm{Y})$ mengalami peningkatan sebesar 0,058 atau $5,8 \%$. Dari hasil uji t untuk variabel yang sama adalah memiliki nilai signifikan 0,050 dimana nilai tersebut lebih kecil dari 0,1 sehingga mempunyai pengaruh positif dan signifikan terhadap kepuasan pelanggan PT. Sucofindo Batam.

Dalam penelitian realibility $\left(\mathrm{X}_{2}\right)$ sangat di perhatikan karena peran dari realibility $\left(\mathrm{X}_{2}\right)$ juga begitu diperlukan untuk dapat lebih meningkatkan kepuaasan pelanggan. Peningkatan realibility $\left(\mathrm{X}_{2}\right)$ dalam pernyataan jasa disampaikan sesuai dengan waktu yang dijanjikan sangat dibutuhkan demi pembaharuan yang semakin baik terhadap kepuasan pelanggan PT. Sucofindo Batam. Hasil ini selaras dengan penelitian yang dilakukan oleh Eswika Nilasari \& Istiatin (2015), dengan jurnal yang berjudul "Pengaruh Kualitas Pelayanan terhadap kepuasan konsumen pada dealer PT. Ramayana Motor Sukoharjo"

\section{Pengaruh Responsiveness $\left(\mathrm{X}_{3}\right)$ Terhadap Kepuasan Pelanggan (Y)}

Faktor ini memiliki 4 item pertanyaan. Dilihat dari tabel hasil uji konstanta dan koefisien regresi diketahui bahwa setiap kenaikan 1 poin atau $1 \%$ dari faktor responsiveness $\left(\mathrm{X}_{3}\right)$ mengakibatkan kepuasan pelanggan (Y) mengalami peningkatan sebesar 0,261 atau $26,1 \%$. Dari hasil uji t untuk variabel yang sama adalah memiliki nilai signifikan 0,035 dimana nilai tersebut lebih kecil dari 0,1 sehingga mempunyai pengaruh positif dan signifikan terhadap kepuasan pelanggan PT. Sucofindo Batam.

Dalam penelitian responsiveness $\left(\mathrm{X}_{3}\right)$ sangat diperhatikan karena peran dari responsiveness $\left(\mathrm{X}_{3}\right)$ juga begitu diperlukan untuk dapat lebih meningkatkan kepuasan pelanggan. Peningkatan responsiveness $\left(\mathrm{X}_{3}\right)$ dalam pernyataan karyawan yang tidak terlalu sibuk sehingga sanggup menanggapi permintaan pelanggan sangat dibutuhkan demi pembaharuan yang semakin baik terhadap kepuasan pelanggan PT. Sucofindo Batam. Hasil ini selaras dengan penelitian yang dilakukan oleh Eswika Nilasari \& Istiatin (2015), dengan jurnal yang berjudul "Pengaruh Kualitas Pelayanan terhadap kepuasan konsumen pada dealer PT. Ramayana Motor Sukoharjo"

\section{Pengaruh Assurance $\left(\mathrm{X}_{4}\right) \quad$ Terhadap Kepuasan Pelanggan (Y)}


Faktor ini memiliki 4 item pertanyaan. Dilihat dari tabel hasil uji konstanta dan koefisien regresi diketahui bahwa setiap kenaikan 1 poin atau 1\% dari faktor assurance $\left(\mathrm{X}_{4}\right)$ mengakibatkan kepuasan pelanggan $(\mathrm{Y})$ mengalami peningkatan sebesar 0,46 atau $4,6 \%$. Dari hasil uji t untuk variabel yang sama adalah memiliki nilai signifikan 0,072 dimana nilai tersebut lebih kecil dari 0,1 sehingga mempunyai pengaruh yang positif dan signifikan terhadap kepuasan pelanggan PT. Sucofindo Batam.

Dalam penelitian ini assurance $\left(\mathrm{X}_{4}\right)$ juga begitu diperlukan, untuk dapat meningkatkan kepuasan pelanggan melalui assurance $\left(\mathrm{X}_{4}\right)$ perlu memperhatikan hal-hal yang dapat menciptakan kepuasan pelanggan (Y) dengan melalui karyawan yang berpengalaman luas serta karyawan yang memberikan rasa aman dan kepercayaan bagi pelanggan. Peningkatan assurance $\left(\mathrm{X}_{4}\right)$ dalam pernyataan perasaan aman sewaktu melakukan transaksi dengan karyawan PT. Sucofindo Batam sangat dibutuhkan demi pembaharuan yang semakin baik terhadap kepuasan pelanggan PT. Sucofindo Batam. Hasil ini selaras dengan penelitian yang dilakukan oleh Imroatul Khasanah \& Octarina Dina Pertiwi (2010), dengan jurnal yang berjudul "Analisis Pengaruh Kualitas Pelayanan Terhadap Kepuasan Konsumen Rs. St. Elisabeth Semarang"

\section{Pengaruh Emphaty $\left(\mathbf{X}_{5}\right) \quad$ Terhadap Kepuasan Pelanggan (Y)}

Faktor ini memiliki 4 item pertanyaan. Dilihat dari tabel hasil uji konstanta dan koefisien regresi diketahui bahwa setiap kenaikan 1 poin atau $1 \%$ dari emphaty $\left(X_{5}\right)$ mengakibatkan kepusan pelanggan (Y) mengalami peningkatan sebesar 0,612 atau $61,2 \%$. Dari hasil uji t untuk variabel yang sama adalah memiliki nilai signifikan 0,000 dimana nilai tersebut lebih kecil dari 0,1 sehingga mempunyai pengaruh positif dan signifikan terhadap kepuasan pelanggan PT. Sucofindo Batam.

Dalam penelitian ini emphaty $\left(\mathrm{X}_{5}\right)$ juga begitu diperlukan, untuk dapat meningkatkan kepuasan pelanggan melalui emphaty $\left(\mathrm{X}_{5}\right)$ hal ini dapat disebabkan oleh pernyataan perhatian individual dari perusahaan sangat dibutuhkan demi pembaharuan yang semakin baik terhadap kepuasan pelanggan PT. Sucofindo Batam.
Hasil ini selaras dengan penelitian yang dilakukan oleh Imroatul Khasanah \& Octarina Dina Pertiwi (2010), dengan jurnal yang berjudul "Analisis Pengaruh Kualitas Pelayanan Terhadap Kepuasan Konsumen Rs. St. Elisabeth Semarang"

\section{Pengaruh Kualitas Pelayanan terhadap Kepuasan Pelanggan PT Sucofindo}

Faktor ini memiliki 4 item pertanyaan. Dilihat berdasarkan hasil analisis regresi berganda bahwa Tangible $\left(X_{1}\right)$, Realibility $\left(X_{2}\right)$, Responsiveness $\left(X_{3}\right)$, Assurance $\left(X_{4}\right)$ dan Emphaty $\left(X_{5}\right)$ secara simultan berpengaruh terhadap Kepuasan Pelanggan (Y). Hasil tersebut diperoleh dari nilai $F_{\text {hitung }}>F_{\text {tabel }}$ $(17.852>1,93)$. Berdasarkan kriteria tersebut maka $\mathrm{H6}$ diterima, artinya pada $\mathrm{H}_{6}$ di buktikan bahwa Tangible $\left(X_{1}\right), \quad$ Realibility $\left(X_{2}\right)$, Responsiveness $\left(X_{3}\right)$, Assurance $\left(X_{4}\right)$ dan Emphaty $\left(X_{5}\right)$ secara simultan berpengaruh terhadap Kepuasan Pelanggan (Y).

\section{SIMPULAN DAN SARAN \\ Kesimpulan}

Berdasarkan hasil analisis data dan pembahasan hasil penelitian dibagian sebelumnya, maka dapat ditarik kesimpulan bahwa:

1. Variabel kualitas pelayanan yaitu tangible secara parsial berpengaruh positif dan signifikan terhadap kepuasan pelanggan.

2. Variabel kualitas pelayanan yaitu reliability secara parsial berpengaruh positif dan signifikan terhadap kepuasan pelanggan.

3. Variabel kualitas pelayanan yaitu responsiveness secara parsial berpengaruh positif dan signifikan terhadap kepuasan pelanggan.

4. Variabel kualitas pelayanan yaitu assurance secara parsial berpengaruh positif dan signifikan terhadap kepuasan pelanggan.

5. Variabel kualitas pelayanan yaitu emphaty secara parsial berpengaruh positif dan signifikan terhadap kepuasan pelanggan.

6. Variabel kualitas pelayanan yaitu Tangible, Realibility, Responsiveness, Assurance dan Emphaty, secara simultan atau bersamasama mempunyai pengaruh yang positif dan signifikan terhadap kepuasan pelanggan. 
Alfi Syahri \& Nur Rahmah, Pengaruh Kualitas Pelayanan (Service Quality) terhadap...

\section{Saran}

Berdasarkan pada hasil dan pemaparan yang telah diuraikan, maka disarankan beberapa hal sebagai berikut:

1. Pada Pada penelitian ini telah diketahui variabel tangible $\left(x_{l}\right)$ memiliki pengaruh positif dan signifikansi terhadap kepuasan pelanggan. Namun berdasarkan tanggapan responden mengenai pernyataan fasilitas fisik sesuai dengan jenis jasa yang ditawarkan masih kurang, maka dari itu saran peneliti adalah :

PT. Sucofindo Batam harus meningkatkan fasilitas fisik berupa fasilitas parkiran pelanggan, fasilitas ruang tunggu dan fasilitas di laboratorium agar pelanggan merasa puas dengan pelayanan PT. Sucofindo Batam.

2. Pada Pada penelitian ini telah diketahui variabel reliability $\left(x_{2}\right)$ memiliki pengaruh positif dan signifikansi terhadap kepuasan pelanggan. Namun berdasarkan tanggapan responden mengenai pernyataan jasa disampaikan sesuai dengan waktu yang dijanjikan masih kurang, maka dari itu saran peneliti adalah:

PT. Sucofindo Batam harus menyampaikan jasa sesuai dengan waktu yang dijanjikan, yaitu dengan membuat tanggal yang ditentukan agar pelayanan sesuai dan tepat waktu sehingga pelanggan merasa puas dengan pelayanan PT. Sucofindo Batam.

3. Pada penelitian ini telah diketahui variabel responsiveness $\left(x_{3}\right)$ memiliki pengaruh positif dan signifikansi terhadap kepuasan pelanggan. Namun berdasarkan tanggapan responden mengenai pernyataan karyawan yang tidak terlalu sibuk sehingga sanggup menanggapi permintaan pelanggan masih kurang, maka dari itu saran peneliti adalah:

PT. Sucofindo Batam harus meningkatkan kualitas karyawannya dengan melakukan pembekalan dan pelatihan kepada karyawan agar sanggup menanggapi permintaan pelanggan.

4. Pada penelitian ini telah diketahui variabel assurance $\left(x_{4}\right)$ memiliki pengaruh positif dan signifikansi terhadap kepuasan pelanggan. Namun berdasarkan tanggapan responden mengenai pernyataan perasaan aman sewaktu melakukan transaksi dengan karyawan PT. Sucofindo Batam masih kurang, maka dari itu saran peneliti adalah:
PT. Sucofindo Batam harus membuat inovasi dan terobosan baru yaitu membuat sistem pembayaran via bank dan transfer mengenai pelayanan pada saat transaksi agar pelanggan merasa aman dan nyaman dengan pelayanan PT. Sucofindo Batam.

5. Pada penelitian ini telah diketahui variabel emphaty $\left(X_{5}\right)$ memiliki pengaruh positif dan signifikansi terhadap kepuasan pelanggan. Namun berdasarkan tanggapan responden mengenai pernyataan perhatian individual dari perusahaan kurang baik, maka dari itu saran peneliti adalah:

PT. Sucofindo Batam harus memberikan perhatian individual secara lebih dengan membuat costumer care dan layanan pelanggan 24 jam terhadap pelanggan hingga merasa puas dan untuk memberikan segala bentuk kemudahan bagi pelanggan PT. Sucofindo Batam.

6. Bagi peneliti selanjutnya yang berminat untuk melanjutkan penelitian ini diharapkan untuk mengembangkan yaitu dengan menggunakan variabel lain yang berpengaruh terhadap kepuasan pelanggan.

\section{Keterbatasan}

Dalam penelitian ini, masih memiliki beberapa keterbatasan antara lain:

1. Metode pengumpulan data yang digunakan hanya kuesioner, akan lebih baik bila ditambahkan metode wawancara langsung kepada pelanggan sehingga informasi dan hasil penelitian yang diperoleh lebih lengkap.

Adanya keterbatasan penelitian dengan menggunakan kuesioner yaitu terkadang jawaban yang diberikan oleh responden tidak menunjukan keadaan sesungguhnya.

\section{DAFTAR PUSTAKA}

Al Karim, R. A. (2014). Costumer Satisfaction On Service Quality In Private Commericial Banking Sector In Bngladesh. British Journal Of Marketing Studies, Vol. 2, No. 2, pp. 1-11.

C.S.Hutasoit. 2011. Pelayanan Publik Teori dan Aplikasi. Jakarta: MagnaScript Publishing, Cetakan Pertama. 
Ghozali, Imam. 2012. Aplikasi Analisis Multivarite Dengan SPSS, Cetakan Keempat, Badan Penerbit Universitas Diponegoro, Semarang.

2012. Aplikasi Analisis Multivariate Dengan Program IBM SPSS 20. Semarang : Badan Penerbit Universitas Dipenegoro.

Husein, Umar. 2009. Metode Penelitian Untuk Skripsi Dan Tesis Bisnis, Edisi Kedua, Rajagrafindo Persada Jakarta.

Khasanah, Imroatul dan Octarina Dina Pertiwi. (2010). Analisis Pengaruh Kualitas Pelayanan Terhadap Kepuasan Konsumen RS St. Elisabeth Semarang. Jurnal. Universitas Diponegoro ISSN 1693-928X. Jurnal Undip Vol. 12, No 2.

Kotler, $\mathrm{P}$ dan Keller. 2007. Manajemen Pemasaran, Edisi 12, Jilid 1, PT. Inseks, Jakarta.

Kotler, Philip. 2008. Principle Of Marketing 12th Edition. Prinsip-prinsip Pemasaran (12th Ed). Ahli Bahasa: Sabran, Bob. Jakarta: Erlangga.

Lovelock, Cristopher, and Jochen Wirtz. 2011. Service Marketing, People, Tecnology, Strategy. New Jersey.

Manoppo, Ferninda. (2013). Kualitas Pelayanan Dan Servicescape Pengaruhnya Terhadap Kepuasan Konsumen Pada Hotel Gran Puri Manado. Jurnal. Universitas Sam Ratulangi Manado ISSN 2303-1174. Jurnal EMBA Vol. 1, No 14.

Nilasari, Eswika dan Istiatin. (2015). Pengaruh Kualitas Pelayanan Terhadap Kepuasan Konsumen Pada Dealer PT. Ramayana Motor Sukoharjo. Jurnal. Universitas Islam Batik Surakarta. Jurnal Paradigma Vol. 13, No. 01, ISSN 1693-0827.

Parasuraman, A. \& Zeithaml, V.A. 2004. Reassessment of Expectations As A Comparison Standard In Measuring Service Quality : Implications For Future Research. Journal Of Marketing

Rayhan. 2010. Sucofindo, Jakarta: Sucofindo Press.
Rizki, Aliftia A. (2014). Pengaruh Kualitas Pelayanan Jasa Verifikasi Impor Terhadap Kepuasan Dan Loyalitas Pelanggan PT Surveyor Indonesia (Persero). Jurnal Aplikasi Manajemen, Institut Pertanian Bogor, Vol 12, No 1, ISSN 1963-5241

Tjiptono, Fandy dan Gregorius Chandra. 2011. Service Quality and Satisfaction (edisi 3). Yogyakarta. Andi

Santoso dan Tjiptono. (2011). Riset Pemasaran Konsep Dan Aplikasi Dengan SPSS. Jakarta: Elex Media Komputindo.

Santoso, Yoan P, Eris Dianawati dan Endi Sarwoko. (2011). Pengaruh Kualitas Pelayanan Terhadap Kepuasan Pelanggan Pengguna Jasa Parkir. Jurnal. Universitas Kanjuruhan Malang. Jurnal Riset Mahasiswa Manajemen ISSN 2337563X. http://ejournal.ukanjuruhan.ac.id

Sugiyono. 2008. Metode Penelitian Kuantitatif Kualitatif Dan $R \& B$, Bandung, Alfabeta.

. 2009. Metode Penelitian Bisnis (Pendekatan Kuantitatif, Kualitatif, $R \& D$, Bandung, Alfabeta. 2012. Metode Penelitian Kuantitatif Kualitatif Dan $R \& B$, Bandung, Alfabeta.

2014. Metode Penelitian Pendidikan (Pendekatan Kuantitatif, Kualitatif Dan $R \& D)$. Penerbit CV. Alfabeta: Bandung.

Santoso, Yoan P, Eris Dianawati dan Endi Sarwoko. (2011). Pengaruh Kualitas Pelayanan Terhadap Kepuasan Pelanggan Pengguna Jasa Parkir. Jurnal. Universitas Kanjuruhan Malang. Jurnal Riset Mahasiswa Manajemen ISSN 2337563X. http://ejournal.ukanjuruhan.ac.id

Sweeney, J. \& Soutar, G. 2006. "Counsumer Perceived Value: The Development of A Multiple Item Scale". Journal Of Retailing, Vol. 7 